\title{
Correction to: Upregulation of IL-15 in the placenta alters trophoblasts behavior contributing to gestational diabetes mellitus
}

Jiaqi Li ${ }^{\dagger}$, Yuan $\mathrm{Li}^{\dagger}$, Xuan Zhou, Lijie Wei, Jingyi Zhang, Shenglan Zhu, Huiting Zhang, Xuan Gao, Lali Mwamaka Sharifu, Shaoshuai Wang, Ling Xi and Ling Feng*

Correction to: Li et al. Cell Biosci (2021) 11:33 https://doi.org/10.1186/s13578-021-00533-4

In this article, there was a mistake in the Western blot photographs of p-JAK1 and p-JAK2 of JAR. The correct version of Figure 6 is given in this erratum (Fig. 6).
All the changes requested are implemented in this correction and the original article [1] has been corrected.

The original article can be found online at https://doi.org/10.1186/s13578021-00533-4.

*Correspondence: ftj007@163.com

†Jiaqi Li and Yuan Li contribute equally to the paper

National Clinical Research Center of Gynecology and Obstetrics, Tongji

Hospital, Tongji Medical College, Huazhong University of Science

and Technology, 1095 Jiefang Anv, Wuhan 430030, Hubei, China to the material. If material is not included in the article's Creative Commons licence and your intended use is not permitted by statutory regulation or exceeds the permitted use, you will need to obtain permission directly from the copyright holder. To view a copy of this licence, visit http://creativecommons.org/licenses/by/4.0/. The Creative Commons Public Domain Dedication waiver (http://creativeco mmons.org/publicdomain/zero/1.0/) applies to the data made available in this article, unless otherwise stated in a credit line to the data. 


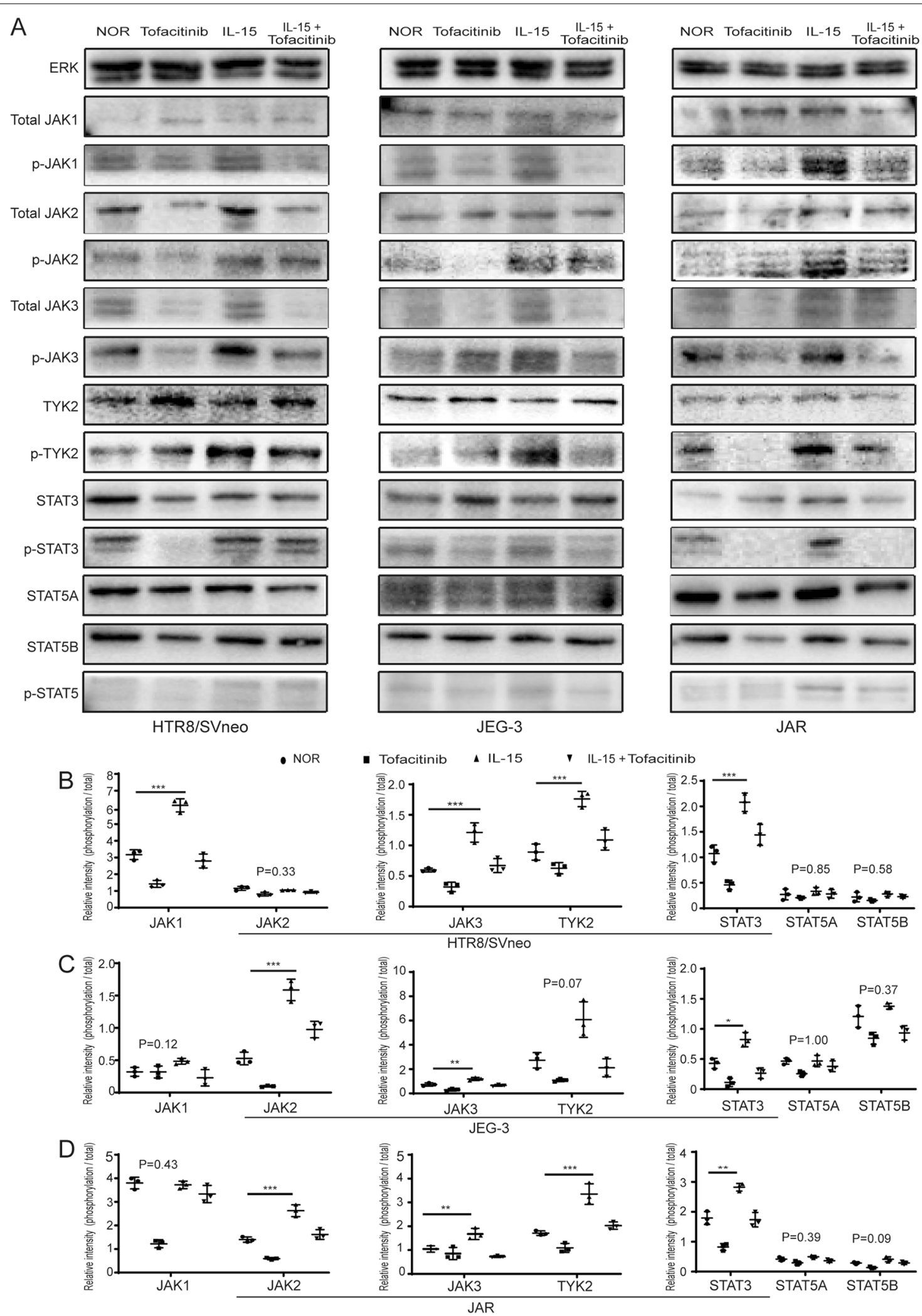

Fig. 6 IL-15 activated the JAK/STAT signaling pathway in trophoblasts in vitro. a Representative of western blot showed the expression of proteins associated with JAK/STAT signaling pathways in different groups of HTR8/SVneo, JEG-3 and JAR. b-d The relative expression of phosphorylation/ total protein in JAK/STAT signaling pathways in different groups of HTR8/SVneo, JEG-3 and JAR. ${ }^{*} P<0.05,{ }^{* *} \mathrm{P}<0.01,{ }^{* * *} P<0.001$ 
Accepted: 19 November 2021

Published online: 13 December 2021

\section{Reference}

1. Li J, Li Y, Zhou X, Wei L, Zhang J, Zhu S, Zhang H, Gao X, Sharifu LM, Wang $S$, Xi L, Feng L. Upregulation of IL-15 in the placenta alters trophoblasts behavior contributing to gestational diabetes mellitus. Cell Biosci. 2021;11:33. https://doi.org/10.1186/s13578-021-00533-4.

\section{Publisher's Note}

Springer Nature remains neutral with regard to jurisdictional claims in published maps and institutional affiliations. 